\title{
Effects Of Hpwss On Employee' Attitude For Korean Firms: The Mediating Role Of Human Resource Competency And The Moderating Role Of Organization Culture
}

Myeong-Ju Lee, Sogang University, South Korea

Dong-Hyun Lee, Sogang University, South Korea

\begin{abstract}
The purpose of this paper is to examine the black box by which high performance work systems (HPWSs) affect employee's attitude. It attempts to show the mediating effect of human resource (HR) competency in the HPWSs-job attitude link, and the moderating effect of organization culture. More specifically, we propose that HPWSs have a positive effect on the both job satisfaction and HR competency, and that HR competency mediates the relationship between HPWSs and job satisfaction. Further, we propose that adhocracy culture in organization strengthens such relationships between HPWSs and HR competency as well as between HPWSs and job satisfaction. We use a nationally representative data set from Korea (firm-level samples: 215 firms, employee-level samples: 5577 employees) for testing the hypotheses. Results indicated support for the hypothesized that positive association between HPWSs and HR competency and between HPWSs and job satisfaction. HR competency has a partial mediating effect in the HPWSjob attitude link. The results were supportive of organization culture of the impact of HPWSs on $H R$ competency and job satisfaction. Limitations of the study and implications for future research are discussed.
\end{abstract}

Keywords: High-Performance; Work Systems; Human Resource Competency; Employee Attitude; Organizational Culture; Job Satisfaction

\section{INTRODUCTION}

esearch on strategic human resource management (SHRM) began in the 1990s (Kehoe \& Wright, 2013). In the field of SHRM, scholars have examined the effects of using a high-performance work system (HPWS) as a tool to maximize a firm's performance (Huselid, 1995; Bae \& Lawler, 2000).

HPWSs refer to a group of separate but interconnected human resource (HR) practices, including strict selective staffing, extensive training and development, incentivized compensation, and performance-based appraisal, all of which are designed to enhance employees' abilities, motivation, and opportunities to contribute, thereby improving organizational performance (Chang \& Chen, 2011; Huselid 1995; Lepak, Liao, Chung, \& Harden, 2006). Relationships between human resource management and organizational performance are described of situationcontingency perspective, universal perspective and configuration perspective (Delery \& Doty, 1996).

Although research, in general, has demonstrated a positive relationship between HPWSs and organizational performance (Arthur, 1994; Delery \& Doty, 1996; Huselid, 1995; MacDuffie, 1995; Wright \& McMahan, 1992), some studies (Delaney \& Huselid, 1996; Wright \& McMahan, 1992) have raised concerns about certain aspects of HPWSs (e.g., inconsistencies in findings on the HR practices-performance relationship). Some of these inconsistencies reported in the literature might be due to the lack of a well-established relationship, either theoretically or empirically, between HPWSs and organizational performance (Delery, 1998; Wright \& Gardner, 
2003). For explaining the inconsistences, situational variables should be investigated in the relationship between HR practices and performances (Lertxundi \& Landeta, 2011). Also, prior SHRM research primarily focused on organizational-level analysis. However, as noted in a number of studies, it is necessary to understand the effect of multiple HR practices on individuals, as employees are considered an important factor in organizational performance.

This research focuses effects of HPWSs on employee. Members of the organization are the most direct stakeholders of human resource management (Colakoglu, Lepak, and Hong, 2006; Gardner, 2000). Therefore, human resource management is not only impact on corporate performance, it would be also necessary to find out what effect the organization members. there is a black box between the human resources management and organization performance that has not been explained, it is that the important issue of human resource management research to unravel these black box(Becker \& Gerhart, 1996; Gerhart, 1996; Wright \& Gardner, 2000)

In this study, we investigated the relationship between HPWSs and organizational performance and the moderating effect of organizational culture. We also examined the mediating effect of human resource capital on the relationship between HPWSs and job attitudes. The purpose of this study is to understand the impact of effective people management on a firm's performance. We build on the universal perspective (Huselid, 1995; Ostroff \& Bowen, 2000) and the contingency perspective (Arthur, 1994; Youndt, Snell, Dean, \& Lepak, 1996), drawing on HPWSs, HR competency, and organizational culture. In summary, our objectives were to: (1) assess the direct link between HPWSs and employees' attitudes, (2) examine the mediating effects of HR competency on these systems and attitudes, and (3) test potential interactive effects between organizational culture, HPWSs, and employees' attitudes.

\section{LITERATURE REVIEW AND RESEARCH HYPOTHESIS}

SHRM studies provide a rich pool of typologies and theoretical support for the contribution of HPWSs to a firm's outcomes (Becker \& Huselid, 1998; Delery \& Shaw, 2001). SHRM studies have primarily explored relationships between a set of HR practices and organizational outcomes adopting universal, contingency, and configuration perspectives. A HPWS is usually defined as a set of HR practices aimed at improving organizational performance, as well as employees' attitudes (Huselid, Jackson, \& Schuler, 1997).

According to previous research on the universal perspective, various initiatives, such as structured career development, internal or external job training, quality circles, and flexible job assignments, enhance employees' abilities, motivation, and opportunity. It also helps firms to attract, recruit, and retain highly capable and qualified individuals who contribute to the firm's performance (Huselid, 1995; Ostroff \& Bowen, 2000). Researchers in the SHRM field have argued that the HR practices and organizational outcomes of firms that adopt single HR practices are less effective than those that adopt a bundle of HR practices (Becker \& Huselid, 1998; Harley, 2002; Macky \& Boxall, 2007).

In research on the contingency approach, Arthur (1994) emphasized that HR practices need to fit the organizational strategy to improve organizational performance. Another study also noted that firms must consider the fit with strategy or external factors, such as organizational culture and national institutions, to increase the effectiveness of HR practices when adopting a HR system (Youndt et al., 1996). Thus, firms with best fit of strategy-HR practices have positively effects on the employee attitude, behaviors, and financial performance (Snell, Youndt, \& Wright, 1996; Wright \& Snell, 1998).

In terms of the configuration perspective, researchers reported that combinations of HR practices influence organizational outcomes (Becker \& Gerhart, 1996; Huselid et al., 1997). Proponents of this approach have argued that congruence among a firm's HR practices is more likely to have a positive effect on organizational performance (Huselid et. al., 1997).

The importance of human capital underpins most SHRM research (Jackson \& Schuler, 1995), with researchers arguing that one important function of HR practices is to improve employee knowledge, skills, and abilities, which, in turn, can be used to create value for the firm (Becker \& Huselid, 1998; Delery \& Shaw, 2001; 
Lado \& Wilson, 1994; Snell, Youndt, \& Wright, 1996). According to Guzzo and Noonan (1994), employees also interpret HR practices as a sign that company managers understand their working conditions.

In the present study, we focused on the relationship between HPWS, one of the bundles of HR practices, and organizational outcomes (HR competency), as well as the attitudes of employees.

\section{Relationship Between HPWSs and Job Satisfaction}

Previous studies demonstrated that HR practices were strongly associated with job satisfaction (Harley, 2002; Macky \& Boxall, 2007). Some researchers have argued that an organization must consider the operation of a HPWS because of its positive effects on employees' attitudes such as job satisfaction, intention to leave, and desire to work hard (Macky \& Boxall, 2007). Firms adopting HPWSs empower employees to make their own decisions or put forward opinions in the workplace (Lawler, 1986). Guest (2002) argued that workers were more satisfied when a HPWS operated in the firm because they had more opportunities to attend internal or external training courses to enhance their skill and knowledge and to obtain more career-related information through discussions with their supervisors and coworkers.

As Guzzo and Noonan (1994) noted, HR practices for dealing with problems in the workplace and employee grievances need to be communicated to employees. Employees' perceptions are affected by the amount that the company invests in them (e.g., education programs, career development opportunities). Thus, we propose that employees are likely to be more satisfied in the firms with HPWSs than without HPWSs. Through elements of HPWSs, such as the job rotation or training initiatives, it is likely that organizational units will better fit employees to jobs. This better fit will increase satisfaction, as employees who perceive that they are well suited to a task are more able to perform their duties efficiently (Kristof-Brown, Zimmerman, \& Johnson, 2005). Further, HPWSs allow for greater information sharing, higher levels of job security, and direct linkages between employee performance and compensation (Becker \& Huselid, 1998; Harley, 2002; Huselid, 1995). Thus, employees in organizations that operate effective HPWSs will be more likely to be satisfied with their work. Therefore, we suggest that:

H1: HPWSs will be positively associated with the job satisfaction.

\section{Relationship Between HPWSs and HR Competency}

Firms need to be able to continuously identify, upgrade, and reinvent valuable Human capital for HR development. Through HR practices, they also apply talent workers in firm to gain advantages in a competitive environment. Theorists in the field of SHRM have strongly suggested that people may be the most powerful source of sustained advantage because traditional sources related to technical skills, financial capital, and economy of scales or scope have been weakened by globalization (Youndt et al., 1996).

According to the theoretical literature on SHRM, HPWSs serve to attract, retain, motivate, and develop human capital in a firm (Coff, 1997; Mueller, 1997). Effectively managing employees provides competitive advantages to firms by developing employee's competencies (Pfeffer, 1994; Wright \& McMahan, 1992). Some researchers have emphasized that employees at all levels form the resource pool for a firm's competency and that firms need to adopt effective HR practices to train and manage their employees and improve their job-related skills and knowledge (Lepak \& Snell, 1999; Bapna, Langer, Mehra, Gopal, \& Gupta, 2013).

Lepak and Snell (1999) theorized that HPWS could significantly promote employees' knowledge, skills, and abilities. Ostroff and Bowen (2000) showed that formal and informal training can enhance employees' knowledge and skills. Delery and Shaw (2001) also emphasized that HR practices (e.g., internal or external training, quality circles, and task force teams) and on-the-job training can enhance the level of job-specific skills among employees. Other studies demonstrated that the emphasis on sharing suggestions in a HPWS setting and the value placed on individual opinions improved work processes and that these contributed to a higher level of employee human capital (Huselid, 1995; Way, 2002). 
Based on the aforementioned, we expect the system of HR practices that incorporate attributes of HPWSs will increasingly improve HR competency. Therefore, we propose that:

H2: HPWSs will be positively related to HR competency.

\section{Relationship Between HR Competency and Job Satisfaction}

Employee motivation is important in an organization because it has a major effect on the employee's performance. Employee motivational issues have become more important to both scholars and managers. According to the literature, employees who are competent in their specific areas show greater job satisfaction and increased work motivation. Herzberg (1966) suggested the motivation factors, such as opportunities for growth and responsibility, fostered job satisfaction. HR competencies, including achievements and improved skills, directly affect employees' attitudes in organizations. For example, improvements in knowledge and skills after training can improve job satisfaction. Based on the above discussion, we propose the following hypothesis:

H3: HR competencies will be positively related to job satisfaction.

\section{Mediating Effect of HR Competency on the HPWS-Job Satisfaction Relationship}

As indicated above, conceptualizations of HPWSs assume that such systems include a set of practices that influence employee motivation and attitudes (Huselid, 1995). Yet, research to date has not tested whether HPWSs predict employees' attitudes (Takeuchi, Chen, \& Lepak, 2009). In this study, we examined the linkages between HPWSs and employees' job satisfaction and propose that HR competency mediates these linkages. Understanding whether and how HPWSs lead to employee job satisfaction is important, as it can help shed additional light on the mechanisms by which HPWSs affect employees' attitudes.

We propose that HR competency provides a means of assessing how HPWSs promote employee job satisfaction. The HR competency literature provides empirical support for the relationship between HR competency and employees' attitudes. To the best of our knowledge, there have been no studies of whether HR competency mediates job attitudes in HPWSs. However, the theoretical and empirical evidence cited above suggests that HR competency underpins job attitudes and that it mediates the relationship between HPWSs and job attitudes. Therefore, we expect the following:

H4: HR competency mediates the relationship between HPWSs and job satisfaction.

\section{Moderating Role of an Adhocracy Culture in an Organization}

Jackson and Schuler (1995) explored various theoretical aspects of HRM. They suggested that many important contextual factors have to be considered to gain a better understanding of the effectiveness of HRM. These include both internal factors, such as technology, size, structure, and strategy, and external factors, such as the labor market, unionization, and national culture. They argued that the organizational culture and HRM cannot be separated in an organization and that the synergy effect on organizational outcomes must be considered in the selection, design, and development of HR systems. Ogbonna and Whipp (1999) also highlighted the important role of organizational culture.

Studies of the effect of the convergence of group members' perceptions of organizational culture reported that they are inclined to interpret relationships and outcomes in similar ways in firms with strong organizational cultures (Mossholder, Bennett, \& Martin, 1998; Yang, Mossholder, \& Peng, 2007). Bowen and Ostroff (2004) suggested that the strength of the organizational climate is an important mediator between HRM systems and a firm's performance. In recent times, Organizational culture studies reported that the relationship between facts of action of firms and affective responses vary depending on organizational culture (Gonzalesz-Roma, Peiro, \& Tordera, 2002; Ehrhart, 2004). For example, Ostroff \& Bowen (2000) propose that the relationship between the facet of innovation and employee satisfaction is moderated by organizational culture encouraging the use of employees' skills. 
According to Cameron and Quinn (1999), organizational culture can be separated into four types: clan, adhocracy, hierarchy, and market cultures. Clan culture is common in family businesses and emphasizes human relations and group culture. Adhocracy culture focuses on change or innovations, such as the development of new products and services or adaptations in business. Hierarchy culture values consistency, cooperation, and conformity among individuals. Market culture places importance on stability and control.

Khatri and Budhwar (2002) reported that HR systems needed to be better aligned with strategies and culture in some Asian companies to increase their performance. Rousseau and Wade-Benzoni (1994) found that HR strategies that encouraged and motivated employees (e.g., via the development of employees' skills and the provision of extensive training) and that emphasized the relational contract and teamwork had stronger organizational cultures (e.g., innovative or adhocracy cultures) than those that did not. Moreover, Sanders, Dorenbosch, and Reuver (2008) found that an innovative culture moderated the relationship between HPWSs within firms and employees' perceptions of work practices. Accordingly, we expect that the effect of HPWSs on HR competencies and job satisfaction will be stronger in firms with than without an adhocracy culture. Therefore, we suggest the following hypothesis:

H5: An adhocracy culture moderates the relationship between HPWSs and job satisfaction.

H6: An adhocracy culture moderates the relationship between HPWSs and HR competencies.

\section{METHODS}

\section{Sample and Data Collection}

The data in this study was collected in the Human Capital Corporate Panel Survey including the variety of questionnaires such as HR practices, employees' attitudes, organizational culture, and organizational performance for Korean firms. This survey was conducted to investigate effects of Human resource management on organization outcome in June 2011 and 2013 respectively by the Korea Research Institute of Vocational Education and Training (KRIVET). The survey was conducted through face-to-face interviews with HR managers and multiple employees from each firm and these employees were randomly chosen for a given firm.

The sample included only publicly traded firms in eight manufacturing sectors (electronics, chemical, metal production, plastics, automotive, semi-conductor, machine equipment, and artificial rubber) according to the twodigit Korean Standard Industry Classification system, with a minimum of 100 employees. Due to missing variables, we excluded some firms from the dataset and finally compose 216 firms and 5577employees for empirical testing.

\section{Measurement and Analysis}

The dependent variables were job satisfaction and HR competencies. Previous research considered various ways of evaluating performance outcomes. Green (2006) and Wright and Boswell (2002) suggested using turnover, satisfaction, commitment, and HR competency as human-related outcomes.

Job satisfaction was captured with a 5-point Likert-type scale, ranging from absolutely do not agree (1) to absolutely agree (5). We measured the job satisfaction according to the method of Schneider et al. (2003), using the following three questions: "I am satisfied with the work I am doing," "I am satisfied with the pay level," and "I am satisfied with about human relations in the company I work for." The internal consistency reliability for job satisfaction was 0.83 , and the intraclass correlation coefficient was 0.8 . Thus, the reliability of the measurement items in this study was acceptable (Fleiss, 1986).

Following prior studies, we measured human-related outcomes using HR competency and job satisfaction. Based on previous research (Spencer, McClelland, \& Spencer, 1994), we employed the following HR competency items: level of overall knowledge, R\&D capabilities, sales, productivity, and administrative support. We calculated the means of the aggregated value of each HR competency item and examined lagged effects of the HPWSs on human-related outcomes by measuring HR competency in 2013 and HR practices in 2011. 
The independent variable was the HPWS. There are several streams of thought about how best to measure HR practices. Delery and Shaw (2001) suggested that most conceptions of HPWSs are based on the assumption that complementarities exist among various HR practices. Thus, additive indices are commonly used to measure HR practices (Appelbaum, Bailey, Berg, \& Kalleberg, 2000; Arthur, 1994; Batt, 2002)

According to previous research, we considered many HR practices as components of HPWSs and then selected the following eight HR practices in HPWSs: off-the-job training, on-the job training, mentoring, flexible job assignments, career development, quality circles, project teams, and suggestion systems (Appelbaum et al., 2000; Choi \& Lee, 2013; Huselid, 1995). These practices are known to improve and develop employees' skill, knowledge, and their abilities to conduct their jobs effectively (Huselid, 1995). To determine the impact of these practices on employee outcome such as job satisfaction and competency, we counted and summed the total number of these practices, if they had such HR practices, HR managers indicate " 1 " in the questionnaires and otherwise " 0 ".

The moderating variable was the degree of an adhocracy culture perceived by employee. The questionnaire contained the following three questions (Cameron \& Quinn, 1999): "Our firm is a very dynamic and innovative place, "people are willing to stick their necks out and take risks," and "our firm emphasizes growth and the acquisition of new resources." We used 5 point Likert-scales ranging from "aboultely do not agree" (1) to "absolutely agree" (5).

The control variables in the firm-level analysis were the size of the firm (logarithm of the number of employees), age of the firm (logarithm of the difference between the year of establishment and 2011), union presence (yes/no), and education level $(1=$ below secondary school, $2=$ high school, $3=$ college, $4=$ university, $5=$ masters, $6=$ Ph.D. or similar). For statistical control, we included industry dummy variables from eight subindustries in the manufacturing area.

We used ordinary least squares (OLS) regression analysis to assess the effect of the HPWSs on HR competency, the mediation effect of HR competency on the relationship between the HPWSs and job satisfaction, and the moderating effect of an adhocracy culture on the relationship between the HPWSs and job satisfaction and between the HPWSs and HR competency.

To test the mediation effect, we adopted the following four regression equations (Baron and Kenny, 1986): regressing the dependent variable on the independent variable (model 1), regressing the mediation variable on the independent variable (model 2), regressing the dependent variable on the mediator (model 3), and regressing the dependent variable on both the independent and mediation variables (model 4).

To assess the moderation effect, we created an interaction term composed of the HPWS and adhocracy culture variables after mean centering each of the independent (HPWS) and moderating variables (adhocracy culture) to reduce multicollinearity.

\section{RESULTS}

\section{Descriptive Statistics}

The correlation matrix in Table 1 presents the descriptive statistics and the correlations for all the variables, except the industry dummies, at the firm level. The mean scores for HR competency and job satisfaction were 3.45 and 3.56. Human competency was employees of moderate ability in the dataset. Job satisfaction of employee was moderate in the firms. The logarithm of the firm's size averaged 5.89, and the logarithm of the firm's age averaged 3.40. An average of $92 \%$ of the firms in the sample had a union. The firms in the sample had an average of $4.44 \mathrm{HR}$ practices. The mean score for Adhocracy culture was 3.34. The magnitude of the correlations was very low and 1.48 was not influenced by multicollinearity (Variance Inflation factor $[\mathrm{VIF}]<2$ ). 
Table 1. Descriptive statistics and correlations

\begin{tabular}{|c|c|c|c|c|c|c|c|c|c|}
\hline Variable & Mean & S.D & 1 & 2 & 3 & 4 & 5 & 6 & 7 \\
\hline $\begin{array}{l}\text { 1. Human resource } \\
\text { competency }\end{array}$ & 3.449 & .511 & & & & & & & \\
\hline 2. Job satisfaction & 3.555 & .300 & $.326^{* *}$ & & & & & & \\
\hline 3. Size of firm & 5.891 & .901 & $.209 * *$ & $.269 * *$ & & & & & \\
\hline 4. Age of firm & 3.402 & .525 & .082 & .020 & $.139 *$ & & & & \\
\hline 5. Union presence & .944 & .230 & .005 & .057 & .061 & .083 & & & \\
\hline 6. Education level & 4.855 & .979 & $.135^{*}$ & $.175^{* *}$ & .119 & .002 & -.124 & & \\
\hline $\begin{array}{l}\text { 7. High-performance } \\
\text { work system }\end{array}$ & 4.444 & 1.379 & $.245 * *$ & $.299 * *$ & $.350 * *$ & .009 & .020 & .045 & \\
\hline 8. Adhocracy culture & 3.337 & .345 & $.285 * *$ & $.669 * *$ & $.156^{*}$ & -.082 & .010 & .098 & $.237 * *$ \\
\hline
\end{tabular}

\section{Tests of Hypotheses}

Table 2 presents the results of the OLS regression analysis of the effects of HPWS on job satisfaction and the mediating effect of HR competency.

In Table 2, the estimated coefficient for the HPWSs in model 1 had a significantly positive effect on job satisfaction $(b=.058 ; p<.001)$, providing support for H1. In model 2 , HPWSs showed a positive, significant association with HR competency $(b=.080 ; p<.01)$, providing support for H2. In model 3 , HR competency also had a significant positive effect on job satisfaction $(b=.062 ; p<.01)$, providing support for $\mathrm{H} 3$. In model 4 , both the HPWS and HR competency had positive $(b=.047 ; b=.129)$ and significant $(p<.01 ; p<.001)$ effects on job satisfaction. HR competency mediated the relationship between the HPWS and job satisfaction through the conditions suggested by Baron and Kenny (1986). The effect of HPWS on job satisfaction was lower in model 4 than in model 1, providing support for H4. These results indicate that employees in firms that operate HPWSs are motivated to continuously improve their ability to contribute to organizational outcomes and that they are satisfied with their working environments.

Table 2. Results of regression analysis of mediation of human resource competency

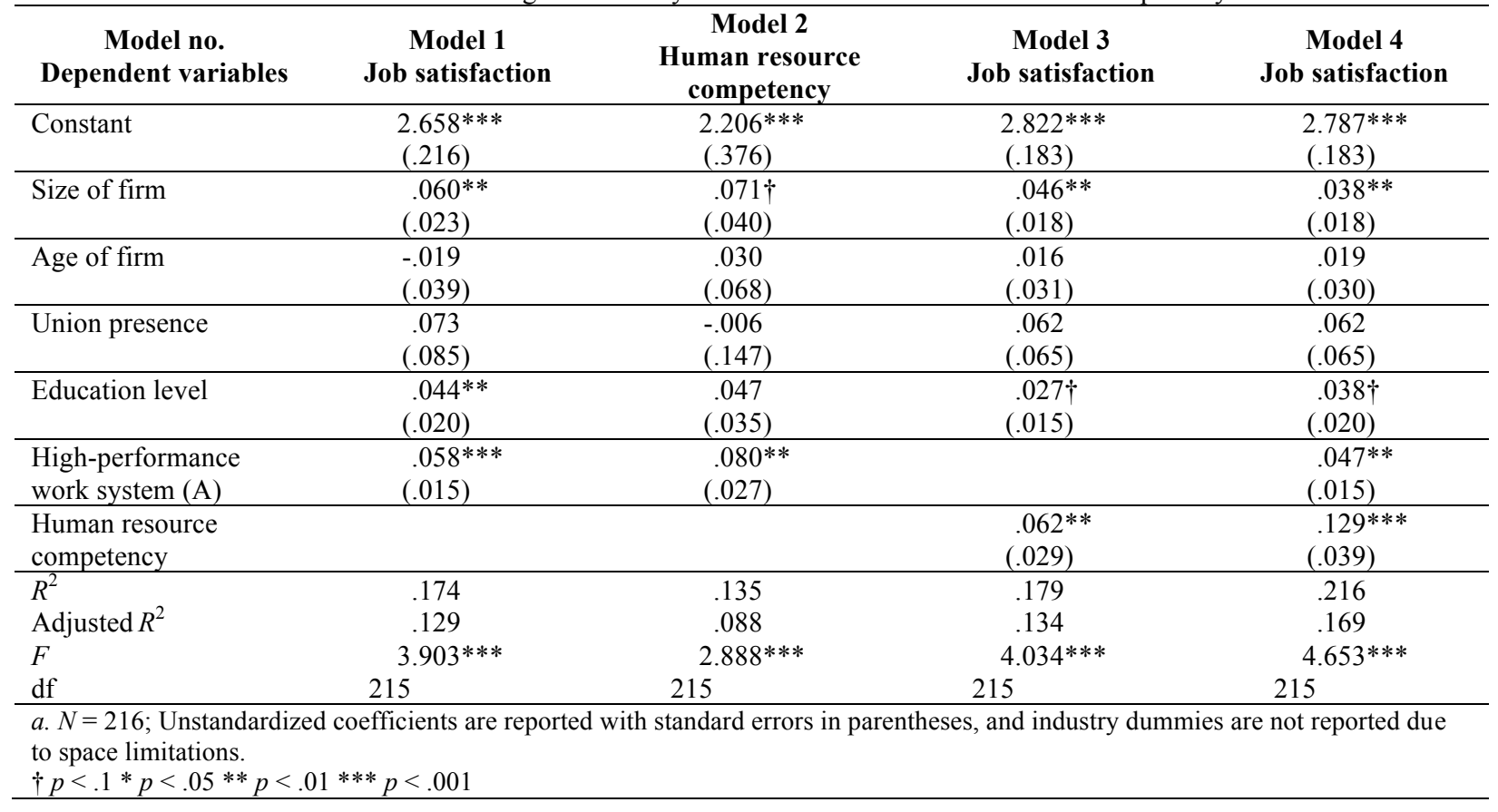


Table 3 reports the results of the OLS regression analysis of the moderating effect of an adhocracy culture. As shown in model 1 and 2 in Table 3, the combination of a HPWS and an adhocracy culture had a positively significant effect on job satisfaction $(b=.081 ; p<.01)$, providing support for H5. This result indicates that the effects of HPWSs on job satisfaction are more positive in firms that have an adhocracy culture. As shown in model 3 and 4 in Table 3, the interaction term of an adhocracy culture and a HPWS had a positive and significant effect on HR competency $(b=.139 ; p<.05)$, providing support for H6.

Table 3. Results of regression analysis of moderators of an adhocracy culture

\begin{tabular}{|c|c|c|c|c|}
\hline $\begin{array}{l}\text { Model no. } \\
\text { Dependent variables }\end{array}$ & $\begin{array}{c}\text { Model } 1 \\
\text { Job satisfaction }\end{array}$ & $\begin{array}{c}\text { Model } 2 \\
\text { Job satisfaction }\end{array}$ & $\begin{array}{c}\text { Model 3 } \\
\text { Human resource } \\
\text { competency }\end{array}$ & $\begin{array}{c}\text { Model } 4 \\
\text { Human resource } \\
\text { competency }\end{array}$ \\
\hline Constant & $\begin{array}{l}.019 * * * \\
(.165)\end{array}$ & $\begin{array}{l}3.019 * * * \\
(.163)\end{array}$ & $\begin{array}{l}2.603^{* * *} \\
(.366) \\
\end{array}$ & $\begin{array}{l}3.017 * * * \\
(.165) \\
\end{array}$ \\
\hline Size of firm & $\begin{array}{l}.041^{*} \\
(.018) \\
\end{array}$ & $\begin{array}{l}.042 * \\
(.018) \\
\end{array}$ & $\begin{array}{l}.061 \\
(.040) \\
\end{array}$ & $\begin{array}{l}.041 * * \\
(.018)\end{array}$ \\
\hline Age of firm & $\begin{array}{l}.023 \\
(.031) \\
\end{array}$ & $\begin{array}{l}.022 * \\
(.030) \\
\end{array}$ & $\begin{array}{l}.055 \\
(.068)\end{array}$ & $\begin{array}{c}.022 \\
(.030) \\
\end{array}$ \\
\hline Union presence & $\begin{array}{l}.063 \\
(.065) \\
\end{array}$ & $\begin{array}{l}.054^{*} \\
(.064) \\
\end{array}$ & $\begin{array}{l}-.009 \\
(.145)\end{array}$ & $\begin{array}{l}.060 \\
(.065)\end{array}$ \\
\hline Education level & $\begin{array}{l}.029 \dagger \\
(.015) \\
\end{array}$ & $\begin{array}{l}.029 \dagger \\
(.015) \\
\end{array}$ & $\begin{array}{l}.037 \\
(.034) \\
\end{array}$ & $\begin{array}{l}.029 \dagger \\
(.015) \\
\end{array}$ \\
\hline $\begin{array}{l}\text { High-performance } \\
\text { work system (A) }\end{array}$ & $\begin{array}{l}.027^{*} \\
(.012) \\
\end{array}$ & $\begin{array}{l}.023 \dagger \\
(.012) \\
\end{array}$ & $\begin{array}{l}.060^{*} \\
(.027) \\
\end{array}$ & $\begin{array}{l}.055^{*} \\
(.027) \\
\end{array}$ \\
\hline $\begin{array}{l}\text { Adhocracy culture } \\
\text { (B) }\end{array}$ & $\begin{array}{l}.538 * * * \\
(.046)\end{array}$ & $\begin{array}{l}.517 * * * \\
(.046)\end{array}$ & $\begin{array}{l}.315^{* *} \\
(.101) \\
\end{array}$ & $\begin{array}{l}.278^{* *} \\
(.102) \\
\end{array}$ \\
\hline $\mathrm{A} \times \mathrm{B}$ & & $\begin{array}{l}.081 * * \\
(.030)\end{array}$ & & $\begin{array}{l}.139^{*} \\
(.067) \\
\end{array}$ \\
\hline $\begin{array}{l}R^{2} \\
\text { Adjusted } R^{2}\end{array}$ & $\begin{array}{l}.514 \\
.486\end{array}$ & $\begin{array}{l}.531 \\
.501\end{array}$ & $\begin{array}{l}.173 \\
.124\end{array}$ & $\begin{array}{l}.190 \\
.138\end{array}$ \\
\hline$F$ & $17.909 * * *$ & $17.607 * * *$ & $3.540 * * *$ & $3.648 * * *$ \\
\hline df & 215 & 215 & 215 & 215 \\
\hline
\end{tabular}

To better interpret the effect of the interaction terms, we plotted the results, using the SD above and below the mean for both the HPWS and adhocracy culture. In Figure 1a, the dashed lines depict a strongly positive relationship between HPWSs and job satisfaction in firms with a strong adhocracy culture. As shown in Figure 1b, the relationship between HPWSs and HR competency was also strongly positive in firms with a solid adhocracy culture. These results graphically support the moderating effect of an adhocracy culture on job satisfaction and HR competency.

Common method variance was not a problem in this study (Podsakoff and Organ, 1986) because information on the independent variable (HPWS) was collected from HR managers, whereas information on the dependent variables was collected from employees (job satisfaction) and managers in the operations department (HR competency). 
Figure 1a. Job Satisfaction

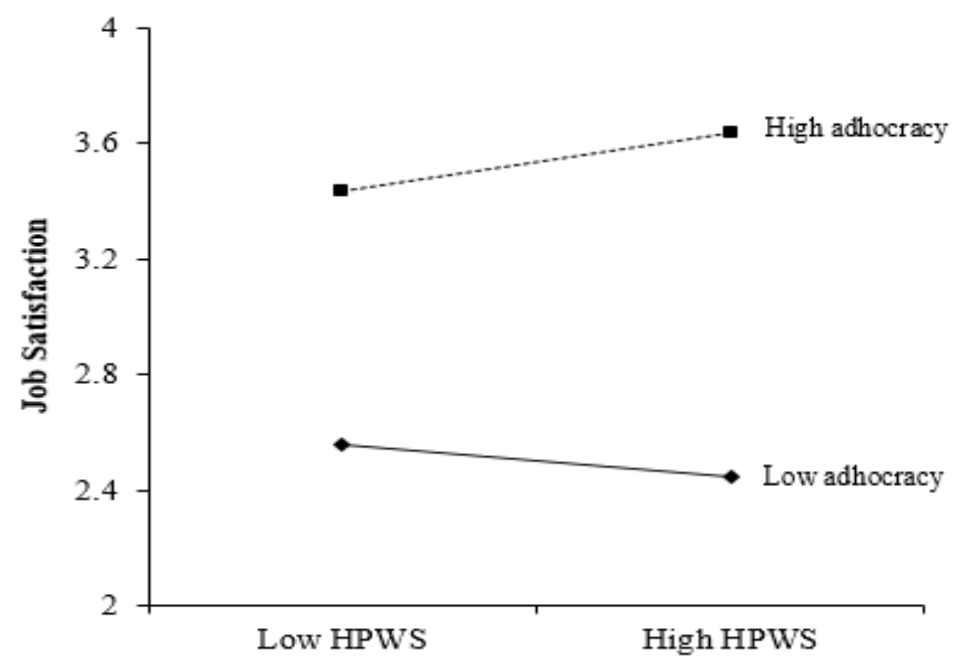

Figure1b. Human resource competency

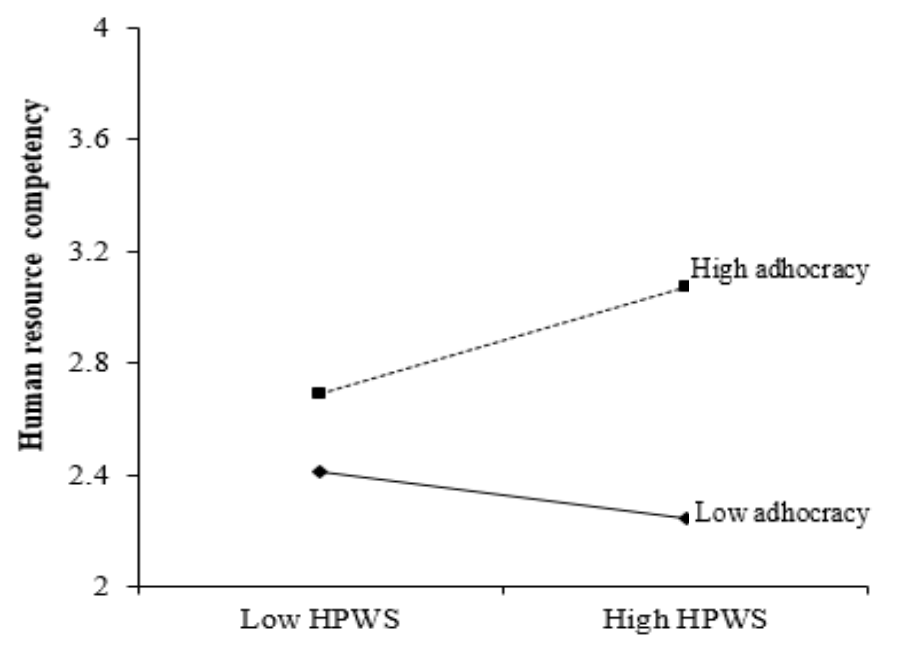

CONCLUSIONS

The purposes of this study were to uncover links between HPWSs and employees' attitudes. This study assumed that HPWSs cannot be successfully implemented without associated increases in employees' competencies, and it focused on organizational culture as a potential mediator of employees' attitudes in HPWSs.

The results of the study provide support for the hypothesized relationships. It showed that although HPWS has direct effects on employees' attitudes, employees' competencies partially mediate the relationships between HPWSs and attitudes. It also demonstrated that the organizational culture moderated the relationships between HPWSs and employees' attitudes and the relationships between employees' competencies and employees' attitudes.

Most studies of SHRM have focused on testing the relationship between HR practices and performances (Becker \& Huselid, 1998; Delery \& Shaw, 2001), and most have found a positive correlation between these practices and organizational performance. Some researchers have argued that examining the internal processes of this relationship is critical to developing theory (Becker and Gerhart, 1996). Therefore, this study investigated the importance of HR competency and the organizational culture in HPWSs and employees' attitudes. The findings confirmed that organizational culture mediates employees' attitudes in firms with HPWSs. 
The findings confirmed that organizational culture plays a moderating role between HPWSs and employees' attitudes. Conceptually, HR practices that emphasize training, evaluation, performance-based rewards, and participation need to be supported by an adhocracy culture.

From a theoretical perspective, the results of this study highlight the need for research to take the situational variables, including culture, of organizations described in studies of SHRM into account (Lertxundi \& Landeta, 2011), when examining the relationship between HR practices and performances.

From a practical perspective, the results may be helpful to organizations adopting many HR systems. Many organizations respond to external environmental pressures by adopting specific systems to ensure their continued legitimacy (DiMaggio \& Powell, 1983). The results of this study emphasize that all HR managers should consider the culture of the organization when implementing HR practices.

There are several limitations in the present study. First, there may be an inverse causal relationship between HR practices and organizational performance (Ostroff \& Schmitt, 1993). In an effort to address this problem, we used data on HR practices for 2011 and data on HR competency and employees' attitudes for 2013 (i.e., time lag). However, it did not fully explain the causal relationship between the two variables. Second, we used HPWSs as a measure bundle of HR practices. Researchers have reached no consensus on whether these should be included in measurements of HR practices (Becker \& Gerhart, 1996; Gerhart, 2007), and there are no common criteria on the best representative practices in HPWSs. Third, there are various HR practices in the field of SHRM. Following a literature review, we investigated eight HR practices. Finally, as this study focused only on manufacturing industries of Korean firms, the generalizability of the study's findings to other industries and countries is limited. Future research should consider a wider range of industries and countries to improve the generalizability of the results.

\section{AUTHOR INFORMATION}

Myeong-Ju Lee (corresponding author) is a doctoral candidate at the Sogang University and a research associate in Laobr Relations and Social Policy Research Division of the Korea Labor Institute.

E-mail: silk@sogang.ac.kr

Dong-Hyun Lee is a doctoral candidate at the Sogang University. His research interests include corporate governance, strategic human resource management, and international business.

E-mail:dhlee83@sogang.ac.kr

\section{REFERENCES}

Appelbaum, E., Bailey, T., Berg, P., \& Kalleberg, A.L. (2000). Manufacturing advantage: Why high-performance work systems pay off. NY: Cornell University Press.

Arthur, J.B. (1994). Effects of human resource systems on manufacturing performance and turnover. Academy of Management Journal, 37, 670- 687.

Baron, R.M., \& Kenny, D.A. (1986). The moderator - Mediator variable distinction in social psychological research: Conceptual, strategic and statistical consideration. Journal of Personality and Social Psychology, $51,1173-1182$.

Bae. J., \& Lawler. J. J. 2000. Organizational and HRM strategies in Korea: Impact on firm performance in an emerging economy. Academy of Management Journal. 43: 502-517.

Bapna, R., Langer, N., Mehra, A., Gopal, R., \& Gupta, A. (2013). Human capital investments and employee performance: an analysis of IT services industry. Management Science, 59(3), 641-658.

Batt, R. (2002). Managing customer services: Human resource practices, quit rates, and sales growth. Academy of management Journal, 45(3), 587-597.

Becker, B. E., \& Huselid, M. A. (1998). High performance work systems and firm performance: A synthesis of research and managerial implications. In Research in personnel and human resource management, 16, 53101.

Becker, B. \& Gerhart, B. (1996). The Impact of human resource management on organizational performance: Progress and Prospects. Academy of Management Journal, 39(4), 779 -801. 
Bowen, D. E., \& Ostroff, C. (2004). Understanding HRM-firm performance linkages: The role of the "strength" of the HRM system. Academy of management review, 29(2), 203-221.

Cameron, K. S., \& Quinn, R. E. (1999). Diagnosing and changing organizational culture. Bk: Addison-Wesley Publishing Company.

Chang, P. C., \& Chen, S. J. (2011). Crossing the level of employee's performance: HPWS, affective commitment, human capital, and employee job performance in professional service organizations. The International Journal of Human Resource Management, 22(04), 883-901.

Choi, J. H., \& Lee, K. P. (2013). Effects of employees' perceptions on the relationship between HR practices and firm performance for Korean firms. Personnel Review, 42(5), 573-594.

Coff, R. W. (1997). Human assets and management dilemmas: Coping with hazards on the road to resource-based theory. Academy of Management Review, 22(2), 374-402.

Delery, J. E. (1998). Issues of fit in strategic human resource management: implications for research. Human Resource Management Review, 8, 289-309.

Delery, J. E., \& Doty, D. H. (1996). Modes of theorizing in strategic human resource management: test of universalistic, contingency, and configurational performance predictions. Academy of Management Journal, 39, 802-835.

Delaney, J. T., \& Huselid, M. A. (1996). The impact of human resource management practices on perceptions of organizational performance. Academy of Management Journal, 39, 949-969.

Delery, J. E., \& Shaw, J. D. (2001). The strategic management of people in work organizations: Review, synthesis, and extension. Research in personnel and human resources management, 20, 165-197.

Ehrhart, M. G. (2004). Leadership and procedural justice climate as antecedents of unit-level organizational citizenship behavior. Personnel Psychology, 57(1), 61-94.

Fleiss, J. L. (2004). The design and analysis of clinical experiments. New York, John Wiley\& Sons.

Gerhart, B. (2007). Horizontal and vertical fit in human resource systems. In C. Ostroff, \& T. Judge (Eds.), Perspectives on organizational fit. SIOP organizational frontiers series. (pp. 317-348) New York: Lawrence Erlbaum Associates, Taylor \& Francis Group.

Green, F. (2006). Demanding Work: The paradox of job quality in the affluent economy. NJ: Princeton University Press.

González-Roma, V., Peiró, J.M., \& Tordera N. (2002). An examination of the antecedents and moderator influences of climate strength. Journal of Applied Psychology, 87, 465-473

Guest, D. (2002) 'Human resource management, corporate performance and employee well-being: Building the worker into HRM. Journal of Industrial Relations, 44(3), 335 - 358.

Guzzo, R. A., \& Noonan, K. A. (1994). Human resource practices as communications and the psychological contract. Human resource management, 33(3), 447-462.

Harley, B. (2002). Employee responses to high performance work system practices: An analysis of the AWIRS95 Data. Journal of Industrial Relations, 44(3). $418-434$.

Herzberg, F. I. (1966). Work and the nature of man. Oxford, England: World Pub.

Huselid, M.A. (1995). The impact of human resource management practices on turnover, productivity, and corporate financial performance. Academy of Management Journal, 38, 635- 670.

Huselid, M.A., Jackson, S.E., and Schuler, R.S. (1997). Technical and strategic human resource management effectiveness as determinants of firm performance. Academy of Management Journal, 40, 171- 188.

Jackson, S. E., \& Schuler, R. S. (1995). Understanding human resource management in the context of organizations and their environments. Strategic Human Resource Management, 46, 237-264.

Kehoe, R. R., \& Wright, P. M. (2013). The impact of high-performance human resource practices on employees' attitudes and behaviors. Journal of Management, 39(2), 366-391

Khatri, N., \& Budhwar, P. S. (2002). A study of strategic HR issues in an Asian context. Personnel Review, 31(2), 166-188.

Kehoe, R. R., \& Wright, P. M. (2013). The impact of high-performance human resource practices on employees' attitudes and behaviors. Journal of Management, 39(2), 366-391.

Kristof-Brown, A. L., Zimmerman, R. D., \& Johnson, E. C. (2005). Consequences of individuals' fit at work: A meta-analysis of person-job, person-organization, person-group, and person-supervisor fit. Personnel psychology, 58(2), 281-342.

Lado, A. A., \& Wilson, M. C. (1994). Human resource systems and sustained competitive advantage: A competency-based perspective. Academy of management review, 19(4), 699-727. 
Lawler III, E. E. (1986). High-Involvement Management. Participative Strategies for Improving Organizational Performance. Jossey-Bass Inc., Publishers, 350 Sansome Street, San Francisco, CA 94104.

Lepak, D.P., \& Snell, S.A. (1999), The human resource architecture: Toward a theory of human capital allocation and development. Academy of Management Review, 24, 31 - 48.

Lepak, D. P., Liao, H., Chung, Y., \& Harden, E. E. (2006). A conceptual review of human resource management systems in strategic human resource management research. Research in personnel and human resources management, 25, 217-271.

Lertxundi, A., \& Landeta, J. (2011). The moderating effect of cultural context in the relation between HPWS and performance: an exploratory study in Spanish multinational companies. The International Journal of Human Resource Management, 22(18), 3949-3967.Locke (1984)

MacDuffie. J. P. 1995. Human resource bundles and manufacturing performance: Organizational logic and flexible production systems in the world auto industry. Industrial and Labor Relations Review. 48: 197-221.

Macky, K., \& Boxall, P. (2007). The relationship between 'high-performance work practices' and employees' attitudes: an investigation of additive and interaction effects. The International Journal of Human Resource Management, 18(4), 537-567.

Mossholder, K. W., Bennett, N., \& Martin, C. L. (1998). A multilevel analysis of procedural justice context. Journal of Organizational Behavior, 19(2), 131-141.

Mueller, D. C. (1997). First-mover advantages and path dependence. International Journal of Industrial Organization, 15(6), 827-850.

Ogbonna, E., \& Whipp, R. (1999). Strategy, culture and HRM: Evidence from the UK food retailing sector. Human Resource Management Journal, 9(4), 75-90.

Ostroff, C., \& Bowen, D. E. (2000). Moving HR to a higher level: HR practices and organizational effectiveness. CA: Jossey-Bass, 211- 266.

Ostroff, C., \& Schmitt, N. (1993). Configurations of organizational effectiveness and efficiency. Academy of management Journal, 36(6), 1345-1361.

Pfeffer, J. (1994). Competitive advantage through people. Boston/Mass.

Podsakoff, P. M., \& Organ, D. W. (1986). Self-reports in organizational research: Problems and prospects. Journal of management, 12(4), 531-544.

Rousseau, D. M., \& Wade-Benzoni, K. A. (1994). Linking strategy and human resource practices: How employee and customer contracts are created. Human Resource Management, 33(3), 463-489.

Sanders, K., Dorenbosch, L., and de Reuver, R. (2008). The impact of individual and shared employee perceptions of HRM on affective commitment: Considering climate strength. Personnel Review, 37, 412-415.

Schneider, B., Hanges, P. J., Smith, D. B., \& Salvaggio, A. N. (2003). Which comes first: employee attitudes or organizational financial and market performance?, Journal of Applied Psychology, 88(5), 836.

Snell, S. A., Youndt, M. A., \& Wright, P. M. (1996). Establishing a framework for research in strategic human resource management: Merging resource theory and organizational learning. Research in personnel and human resources management, 14, 61-90.

Spencer, L. M., McClelland, D. C., \& Spencer, S. M. (1994). Competency assessment methods: History and state of the art. Hay/McBer Research Press.

Takeuchi, R., Chen, G., \& Lepak, D. P. (2009). Through the looking glass of a social system: Cross-level effects of high-performance work systems on employees' attitudes. Personnel Psychology. 62(1), 1-29

Yang, J., Mossholder, K. W., \& Peng, T. K. (2007). Procedural justice climate and group power distance: an examination of cross-level interaction effects. Journal of Applied Psychology, 92(3), 681.

Youndt, M. A., Snell, S. A., Dean, J. W., \& Lepak, D. P. (1996). Human resource management, manufacturing strategy, and firm performance. Academy of management Journal, 39(4), 836-866.

Way, S. (2002). High Performance Work systems and intermediate indicators of firm performance within the US small business sector. Journal of Management, 28(6), 765 - 85.

Wright, P. M., \& Boswell, W. R. (2002). Desegregating HRM: A review and synthesis of micro and macro human resource management research. Journal of management, 28(3), 247-276.

Wright, P. M., Gardner, T. M., \& Moynihan, L. M. (2003). The impact of HR practices on the performance of business units. Human Resource Management Journal, 13(3), 21-36.

Wright, P.M., and McMahan, G.C. (1992). Theoretical perspectives for strategic human resource management. Journal of Management, 18, 295-320. 